\title{
The effect of financing using the principle of profit-loss sharing on profitability level of commercial Islamic bank registered in Bank Indonesia
}

\author{
Nurul Alfi Syahri, D. Agus Harjito* \\ Department of Management, Faculty of Business and Economics, Universitas \\ Islam Indonesia, Yogyakarta, Indonesia \\ *Corresponding author: agus_h@uii.ac.id
}

\author{
Article History \\ Received, 9 March 2020 \\ Revised 1, 23 March 2020 \\ Revised 2, 12 April 2020 \\ Accepted, 10 May 2020
}

\begin{abstract}
Purpose: This study aims to examine the effect of financing products with the principle of profit-loss sharing offered by Sharia Banks to the level of profitability of Sharia Banks. The financing product under profit sharing principle of Sharia Bank can be categorized into two types namely Mudharaba and Musharaka. The effect of Mudharaba and Musharaka on the profitability level of Sharia Banks is tested partially and simultaneously. In this study, the profitability level of Sharia Bank is measured by Return On Equity (ROE).

Methodology: The sample of this research is the Sharia Bank registered in Bank Indonesia. The sample selection in this study used purposive sampling method and obtained6 samples for the study period of 2012-2016. This research uses Multiple Linear Regression analysis method to analyze the data.
\end{abstract}

Findings: Results of this study indicate that financing products with profit-loss sharing principles represented by the proxy of Mudharaba and Musharaka have a significant effect on the profitability level of Sharia Banks for the period of 20122016. Mudharaba is partially significant and positive to the profitability level of Sharia Banks for the period of 2012-2016, Musharaka partially has a significant and negative effect on the profitability level of Sharia Banks for the period of 2012-2016, and Mudharaba and Musharaka simultaneously have a significant influence to the level of profitability of Sharia Banks for the period of 2012-2016.

Originality: This study enriches the discussion of the effect of financing products with the principle of profit-loss sharing offered by Sharia Banks to the level of profitability of Sharia Bank. The effect of Mudharaba and Musharaka on the profitability level of Sharia Banks is tested to the profitability level of Sharia Banks

Keywords: Mudharaba, musharaka, profitability, ROE, sharia bank
Cite this article:

Syahri, N A., \& Harjito, D A. (2020). The effect of financing using the principle of profit-loss sharing on profitability level of commercial Islamic bank registered in Bank Indonesia, Asian Journal of Islamic Management, 2(1), 46-58. DOI: 10.1108/AJIM.vol2.iss1.art5

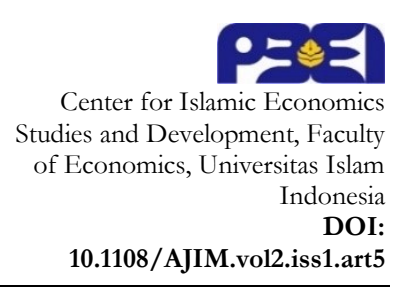

\section{Introduction}

The bank is one of the financial institutions that play an important role as a national economic booster as it is functioning as the intermediary between parties who have fund surplus and those who are deficit in funds. This financial institution works as an effective and productive saving 
facility for the public and accelerates payment traffic for any economics sectors. Many people who run businesses decide to partner with banks to gain capital, as they need a lot of money to operate their business. This partnership shows the bank's role as the intermediary institution operating to support society's living standards.

Muhammad (2005) explains in his book that there are two types of banks based on its principle. They are the conventional one and the Islamic (sharia) one. The Islamic bank is the type of bank which collect funds from society and distribute it to the needs in term of increasing welfare and the distribution scheme is based on sharia law. In other words, the Islamic bank is a financial institution which its core activity is to provide financing and other services in payment traffic and money circulation with sharia law as its operating basis.

The Islamic bank has various financing system, such as murabahah; Mudharaba; Musharaka; ijarah; salam; istishna; and qardh. According to Khan (2011) murabahah is the most popular type of financing indicated by a bigger percentage of assets value compare to other Islamic financial instruments, however, Mudharaba and Musharaka are the two types of financing that dominate Islamic bank in Indonesia. According to Muhammad (2005), financing is funding activity given to a certain party from the other to support planned investment. Under the term of financing in Islamic banks, it is technically called the productive asset. Financing is a business product that generates profits to Islamic banks.

Muhammad (2005) explains that Mudharaba financing is an agreement between capital owner and entrepreneur who is capable or experienced in a certain project, wherein this circumstance, the capital owner acts as the supervisor and the whole business is run by the entrepreneur. If there any failures occur and material loss is included, the capital owner will fully take over the responsibility, unless if the mistakes were intended by the entrepreneur. Musharaka financing, according to Botis (2013) is an agreement between two parties or more with a capital owner who has already agreed to take the partnership and run businesses together as partners. In this scheme, if failures occur, all parties will be given the responsibility to handle the loss based on how much capital each party contributes.

Financing operational activity done by Islamic banks can be considered effective and efficient in generating company profit by reflecting on the profitability ratio. Profitability is one of the analytic tools used to assess management performance in generating profit from the bank's business operation. High profitability may indicate good financial performance, while low profitability indicates a less maximum financial performance in its effort to generate profit. If this low profitability is being ignored continuously, it will result in low brand image of the bank in people's perception and lower their trust. The decreasing of people's trust can lead to fundcollecting issues. To escalate profitability, efforts should be made to increase the maximization of profit generation, it can be done by utilizing productive asset. The productive asset will generate profit if the company distributes the fund to society in the form of various works. The work should be evenly distributed as well since productive asset management will affect profit generation. The bigger the productive asset utilized, the more profit will be generated (Fatmawati, 2016).

Permata et al (2014) find the relationship between Mudharaba and Musharaka toward Islamic bank profitability is that every bank must collect fund and allocate them to other activity that results to profit. One way to allocate the fund is by implementing Mudharaba and Musharaka financing. The two financing types will generate profit from the profit-sharing calculation. The profit gained will be shared between the bank and the customer. The profit will be used to return the capital which was allocated to the financing. The rate of return on capital can measure the profitability level of a certain bank by comparing the profit and the capital owned by it.

Profit can be analyzed from the profitability level which is measured using financial ratio. The financial ratio used to measure profitability level are Return On Asset (ROA), Return On Investment (ROI), Return On Equity (ROE), profit margin, and Basic Earning Power or economics profitability ratios. In this research, the profitability level is measured using the Return On Equity (ROE) proxy. It is the rate of return on the capital of the analyzed bank. The reason 
for using this ratio is to understand the bank's capability in managing its capital to do the Mudharaba and Musharaka financing. The authors choose the Return On Equity (ROE) proxy in profitability ratio as the parameter to measure financial performance. Profitability analysis is very important to assess management's capability in generating profit.

Permata et al (2014) in their research find that Mudharaba financing negative and significantly affects ROE level, while Musharaka financing positive and significantly affects ROE level in partial. Simultaneously, Mudharaba and Musharaka financing significantly affect the ROE level, the same as the result of the research of Fatmawati (2016) which stated that simultaneously, Mudharaba, Musharaka, and murabahah financing do not significantly affect ROA but do positive and significantly affect ROE. Different from this research, research conducted by Haeruddin (2016) shows that Mudharaba saving has a positive effect toward Return On Asset (ROA), where the correlation analysis result shows that Mudharaba does not significantly affect Islamic bank profitability. Ismail and Tohirin (2010) in their research stated an argument that the contract of Mudharaba and Musharaka is profit-loss sharing mechanisms that consist of the corporation spirit to increase profit in the effort of Islamic objective through economics activity.

Haeruddin (2016) stated that Mudharaba saving has a positive effect on the bank's profitability level, in which, the Mudharaba saving increase, the profitability level will escalate as well, and vice versa. Further, the result of correlation analysis shows that the relationship between saving and Mudharaba profitability is 0.472 , while the coefficient of determination is $\mathrm{r} 2=0.2323$ or $22.3 \%$, which means the contribution of Mudharaba saving to bank profitability is as high as $22.3 \%$ while the rest is determined by other factors $(77.7 \%)$.

Permata et al (2014) stated that Mudharaba financing has a positive and significant impact on the ROE level partially. Simultaneously, Mudharaba and Musharaka significantly affect the ROE level. Mudharaba is a profit-sharing financing type that has the most domination toward the ROE level. On the other hand, Wibowo and Sunarto (2015) stated that Mudharaba and Musharaka financing positively affect ROE simultaneously. Aditya (2016) also explains that Mudharaba and Musharaka financing have a positive and significant effect on profitability level of the Commercial Islamic Bank during 2010-2014.

\section{Literature Review \& Hypothesis Development}

\section{Profitability}

Horne and Wachowiz (2013) stated that the profitability ratio is a ratio which connects profit with sales and investment. Profit indicates how good investment and financing decisions are made by a company. In the banking financial report, profitability ratio a tool to measure the effort efficiency level that is created by a certain company, moreover, profitability is also defined as the bank's capability in generating profit. A profitability ratio is divided into 4 components: Basic Earning Power (BEP) or economic profitability, Return on Equity (ROE), Return on Investment (ROI) or Return on Assets (ROA), and Profit Margin.

1. Basic Earning Power (BEP) or Economics Profitability

Economics profitability or Basic Earning Power (BEP) is a comparison between business profit or operational profit and owned asset (owned capital and external capital that is used) and stated in the form of a percentage. This ratio is used to measure assets' capability to generate operational profit.

$$
\mathrm{BEP}=\left(\frac{\text { operational profit }}{\text { the average of asset }}\right) \times 100 \%
$$

2. Return on Equity (ROE)

Horne and Wachowicz (2013) explain that the Return on Equity (ROE) is the result of the comparison between the sum net profit after tax (deducted by common stock dividend) and 
total equity invested by stockholders into the company and is stated in the form of a percentage. This ratio is used to measure how much profit gained from capital management.

$$
\mathrm{ROE}=\frac{\text { nett profit after tax }}{\text { stock holder equity }} \times 100 \%
$$

3. Return on Investment (ROI) or Return on Asset (ROA)

Return on Investment (ROI) and Return on Asset (ROA) is the same. Horne and Wachowicz (2013) stated that Return on Investment (ROI) is the result of the comparison between net profit after tax and the total asset owned and is stated in the form of a percentage. Return on Investment (ROI) reflected management's capability in optimally allocating their asset so that expected profit can be generated. This ratio is used to measure how much profit generated from the result of asset management.

$$
\text { ROI }=\frac{\text { nett profit after tax }}{\text { total asset }} \times 100 \%
$$

4. Profit Margin

Profit margin is the comparison result between net profit after tax (operational profit) and total sales. It is stated in the form of a percentage. Profit margin is a capability measurement to understand the company's capability to generate profit compared to how many sales achieved by the company. This profit margin ratio is used to measure how much profit generated from every sale (Horne and Wachowicz, 2013).

$$
\mathrm{PM}=\frac{\text { nett profit after tax }}{\text { sales }} \times 100 \%
$$

This research uses the Return on Equity (ROE) projection to understand the profitability level of the Commercial Islamic Bank. Horne and Wachowicz (2013) explain that Return on Equity (ROE) is an indicator to measure management's capability in managing provided capital to generate profit. The higher the ratio of Return on Equity (ROE), the better the company can generate profit.

\section{Financing with Profit-Loss Sharing Principle}

Financing is funding given by a party to another to support planned investments, be it individual or institutional. Financing distribution is the activity that dominates fund allocation in the Islamic bank.

1. Mudharaba Financing

Muhammad (2005) stated that al Mudharaba derives from the word dharb which means to hit or to walk. The meaning of to hit or to walk in this term specifically indicates the process of somebody hitting his leg to do some works. Technically, Mudharaba agreement is a cooperation agreement between two parties where the first party acts as the shahibul maal or investor, and the other acts as mudharib or the management. The profit generated under this Mudharaba financing is shared based on the signed agreement, meanwhile, if any loss occurred, the responsibility to take over will be given to the investor, except the loss was intentionally caused by the management. The financing contract of Mudharaba agreement consists of two types, they are Mudharaba muthlaqah and Mudharaba muqayyadah. Mudharaba muthlaqoh is the agreement where the banks or issuer (Special Purposive Vehicle or SPV) have full rights to determine where the capital fund will be distributed. Meanwhile, the Mudharaba muqayyadah is the agreement where the banks or the issuer (Special Purposive Vehicle or SPV) and the investor (shahibul maal) make an early agreement to choose together where the capital fund will be distributed. 
2. Musharaka Financing

Al Musharaka is a cooperation agreement between two parties or more on a certain work where each party will contribute in the form of fund or skill with a specific agreement that the profit and loss will be all parties' responsibility under the content of the agreement (Muhammad, 2005).

Every bank collects fund and allocated the fund to other activity that generates profit. One way to allocate the fund is through Mudharaba and Musharaka financing. Both financing schemes will generate profit from the profit-sharing estimation. The profit will be shared between the bank and the customer who manage the fund. The profit will be used to return the capital allocated to the financing. The rate of return on capital can measure the profitability level of the bank by comparing the profit/loss and the owned capital (Permata et al, 2014).

\section{Theoretical Framework}

The theoretical framework developed in this research is based on various references. The research framework is used as the research model so that the authors will get easier to analyze research data. According to Sekaran (2003), the theoretical framework is a foundation where all research projects relied on.

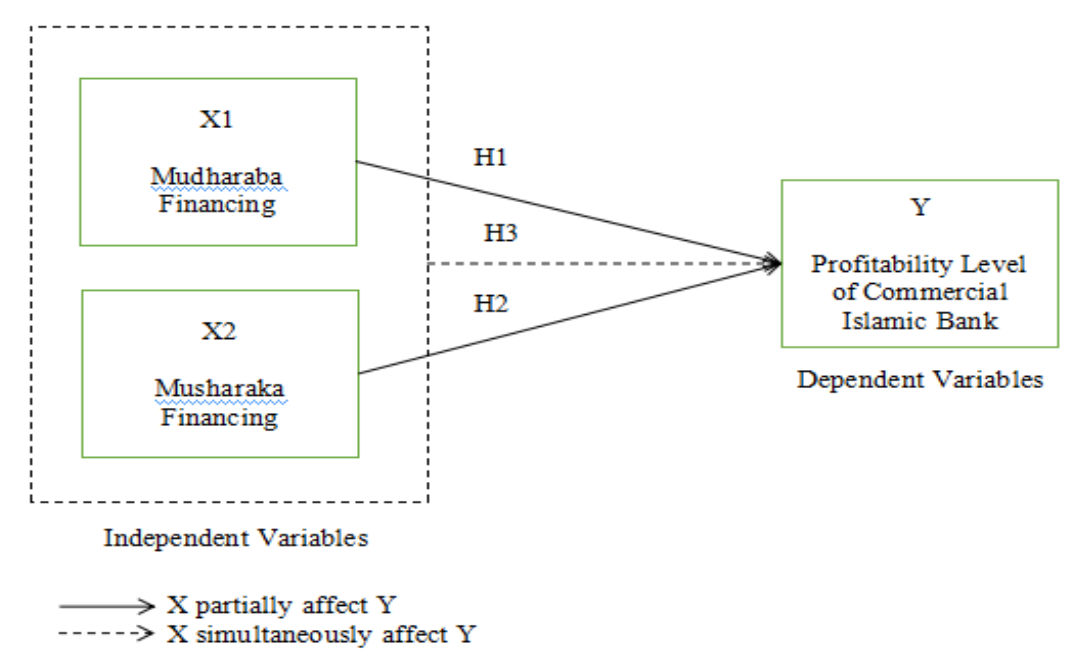

\section{The Effect of Mudharaba Financing toward Profitability}

Mudharaba financing is the cooperation agreement between two parties, where the first party serves as the fund provider (shahibul maal) and the other one serves as the fund manager (mudharib) (Muhammad, 2005). Normally, when the Mudharaba financing is increased, then the profitability level will go up as well because every value of the financing will generate profit which contributes to the increase of profitability level percentage. According to Aditya's research (2016), it is stated that Mudharaba financing has positive and significant effect on the profitability level of the Commercial Islamic Bank during 2010-2014. This fact is proven by the regression coefficient value as high as 0.003136 and the value of the $t$ count $\left(t_{h}\right)$ that is bigger than the value of the $t$ table $\left(\mathrm{t}_{\mathrm{t}}\right)$ with $5 \%$ significance where the $\mathrm{t}$ count $\left(\mathrm{t}_{\mathrm{h}}\right)$ as much as 5.506 and the $\mathrm{t}$ table $\left(\mathrm{t}_{\mathrm{t}}\right)$ as much as $1.701(5.506>1.701)$. other than that, the value of significance probability (p. value) is 0.000 shows a smaller number from the determined significance number (alpha) of 0.05 . Haeruddin's research (2016) explains the research result shows that Mudharaba saving has a positive impact on Return on Asset (ROA).

$\mathrm{H} 1=$ Mudharaba financing has a positive effect on the profitability level of the Commercial Islamic Bank registered in Bank Indonesia. 


\section{The Effect of Musharaka Financing toward Profitability}

Musharaka financing is a cooperation agreement between two parties or joint venture cooperation to generate profit. The profit is shared based on the agreement, while the loss will be shared based on fund contribution from each party. Musharaka agreement is normally used in investment projects, letter of credit, and real estate or property purchases (Botis, 2013). When the Musharaka financing increase, the profitability should increase as well because every value of the financing will generate business profit that will lead to an increase in profitability percentage. According to Permata et al (2014), it is stated that Musharaka financing has a positive and significant effect on ROE partially. Wibowo and Sunarto (2015) also find in their research that the t-test of Musharaka financing shows that the value of $\mathrm{p}<\alpha(0.000<0.05)$, which means it has a significant effect. It is concluded that Musharaka financing has a positive and significant result toward profitability which projected by Return on Equity (ROE).

$\mathrm{H} 2=$ Musharaka financing has a positive effect on the profitability level of the Commercial Islamic Bank.

\section{The Effect of Mudharaba and Musharaka Financing toward Profitability}

The increase of Mudharaba and Musharaka financing, normally, will affect the increase of profitability because every value of the financing will generate profit that will cause an increase in profitability percentage. Fatmawati (2016) in their thesis paper stated that, simultaneously, Mudharaba, Musharaka, and murabahah financing do not have any significant effect on ROA but have a positive and significant effect on ROE. Permata et al (2014) in their research stated that, simultaneously, these Mudharaba and Musharaka financing have a significant effect on ROE level. Moreover, according to the thesis paper of Aditya (2016), it is stated that Mudharaba and Musharaka financing have a positive and significant effect on the profitability level of the Commercial Islamic Bank during 2010-2014. This is proven by the bigger F count value compared to the $\mathrm{F}$ table value with a $5 \%$ significance rate. The $\mathrm{F}$ count is as much as 16.59 while the $\mathrm{F}$ table is as much as $3.35(16.59>3.35)$. Other than that, the value of significance probability is 0.000 . It shows a smaller number than the determined significance rate which is 0.05 .

$\mathrm{H} 3$ = Mudharaba and Musharaka financing have a positive effect on the profitability level of the

Commercial Islamic Bank simultaneously.

\section{Methods}

This research is associative research. According to Aditya (2016), associative research is research to understand the relationship between two variables or more. With this type of research, a certain theory can be built to expect and control certain phenomena. The data collected in this research is in the form of a number, thus, categorize the research as the quantitative one. This research uses the annual Commercial Islamic Bank financial report as its secondary data.

This research is conducted to the Commercial Islamic Banks registered in Bank Indonesia, based on accessed data on the site of www.bi.go.id. The data which is used is the secondary data from the annual financial report of the Commercial Islamic Banks which are published between 2012-2016, while the research itself is conducted from the end of 2017 up to early 2018.

\section{Research Variables}

Sekaran (2011) stated that research variables are anything that can differ and contribute variation to the value. Value can be different from time to time for the same object or subject. Value can also be different in terms of the subject and object within the same time-frame. The variables used in this research consist of two variable types, which are dependent and independent 
variables. The dependent variable $(\mathrm{Y})$ is profitability which projected by Return on Equity (ROE), while the independent variables are Mudharaba (X1) and Musharaka (X2) financing.

\section{Sample and Population}

The population is the total scope of the research which includes any objects or subjects that have certain characteristics to be analyzed, studied, and concluded, determined by the researchers. A population can be a group of people, data, event, or any object that have certain characteristics. The population of this research is Islamic banks registered in Bank Indonesia as listed below in Table 1.

Table 1. List of Research Population

\begin{tabular}{cl}
\hline No & \multicolumn{1}{c}{ Name } \\
\hline 1 & Bank Muamalat Indonesia \\
2 & Bank Victoria Syariah \\
3 & Bank BRI Syariah \\
4 & Bank Jabar Banten Syariah \\
5 & Bank BNI Syariah \\
6 & Bank Syariah Mandiri \\
7 & Bank Mega Syariah \\
8 & Bank Panin Syariah \\
9 & Bank Syariah Bukopin \\
10 & Bank BCA Syariah \\
11 & BTPN Syariah \\
\hline \multicolumn{2}{l}{ Source: Bank Indonesia (www.bi.go.id accessed on April 15, 2017) }
\end{tabular}

The sample is a part of all populations. In this research, the sample is determined by purposive sampling method. The criteria of the sample are:

1. Commercial Islamic Bank registered in Bank Indonesia

2. Commercial Islamic Bank published its annual financial report in Rupiah from December 31, 2012, up to 2016.

3. Commercial Islamic Bank that has complete data in regards to Mudharaba and Musharaka financing during 2012-2016 to be analyzed.

Based on considerations, below is the list of chosen banks as the sample of this research:

Table 2. List of Research Sample

\begin{tabular}{cl}
\hline No & \multicolumn{1}{c}{ Name } \\
\hline 1 & Bank Muamalat Indonesia \\
2 & Bank BRI Syariah \\
3 & Bank Syariah Mandiri \\
4 & Bank BNI Syariah \\
5 & Bank Panin Syariah \\
6 & Bank BCA Syariah \\
\hline
\end{tabular}

The authors analyzed data based on the six Commercial Islamic Bank samples during the period of 2012-2016.

\section{Data Collection Technique}

This research is using the documentation method as its data collection technique. This documentation method is conducted by gathering secondary data from the Islamic bank's official website. The gathered data was in the form of a financial report during 2012-2016 and other data related to the dependent and independent variables. 


\section{Result and Discussion}

\section{Statistical Descriptive Analysis}

This research analyzed Mudharaba and Musharaka financing and ROE level data during 2012-2016. The data is collected from Bank BNI Syariah, Bank Muamalat Indonesia, Bank Syariah Mandiri, Bank BRI Syariah, Bank BCA Syariah, and Bank Panin Syariah. Based on this research results, the lowest Mudharaba financing is found in Bank Panin Syariah (Rp517.354.418) in 2012, meanwhile, the highest number can be found in Bank Syariah Mandiri (Rp4.161.500.769.523) on 2012. The average number of this financing is Rp1.167.686.163.325. Bank Panin Syariah also has the lowest number of Musharaka financing in 2012 (Rp229.960.632), meanwhile, Bank Muamalat Indonesia has the highest number of Musharaka financing in 2012 (Rp20.192.427.340.000). The average number of this Musharaka financing is Rp5.525.776.650.882. Estimated using the ROE, Bank Syariah Mandiri has the highest ROE level (19.27\%), while the lowest number is scored by Bank BRI Syariah $(0.39 \%)$.

\section{Classic Assumption Test}

The classic assumption test is conducted to understand the coefficient number to avoid biases. This test should be done first before conducting the multiple regression analysis. Below are the results of the classic assumption test:

Table 3. Classic Assumption Test Result

\begin{tabular}{lccc}
\hline & & Sig. & Conclusion \\
\multicolumn{2}{c}{ Kolmogorov-Smirnov (Normality) } & 0,200 & Normal Data \\
\hline Heteroscedasticity & Mudharaba & 0,761 & Non-Heteroscedasticity \\
Multicollinearity & Musharaka & 0,583 & \\
& Mudharaba & 0,024 & Non-Multicollinearity \\
& Musharaka & 0,001 & \\
& Simultaneous & 0,246 & \\
\hline \multicolumn{2}{l}{ Durbin-Watson (Autocorrelation) } & 1,838 & Non-Autocorrelation \\
\multicolumn{2}{l}{ Source: Processed data } & &
\end{tabular}

\section{a. Data Normality Test}

The normality test is conducted to test the distribution number of variables residual. A good regression model is when the data is normally distributed or have proportionate distribution to represent the population data. The normality test can be tested using the Chi-Square, Lilifors test, and Kolmogorov-Smirnov test. In this research, the normality test conducted using Kolmogorov-Smirnov, where the data can be considered normally distributed when the sig. Value is bigger than than $\alpha=5 \%(0,05)$.

Based on the result of the data normality test, Mudharaba and Musharaka financing variables have Kolmogorov-Smirnov value as high as 0.127 with a significance value 0.200 . This 0.200 value is greater than the 0.05 alpha, thus the data can be considered normally distributed.

\section{b. Heteroscedasticity Test}

The heteroscedasticity test is conducted to find out whether there is a deviation in the classic assumption of heteroscedasticity which means the variance inequality from the residual of all regression model observation. A proper regression model is the one with the same residual variance on any observation. Statistical tests that can be used are the Gletser test, Park test or White test, and Spearman Correlation Coefficient test. This research is using Gletser test to measure the heteroscedasticity. 
The Gletser test shows that the sig. value of Mudharaba financing is 0.761 and Musharaka financing is 0.583 . These values are greater than the $\alpha=5 \%(0,05)$ so that it can be concluded that the data on Mudharaba and Musharaka financing do not show any heteroscedasticity.

\section{c. Multicollinearity Test}

The multicollinearity test is conducted to measure whether there is any high correlation (connection) between independent variables in a linear multiple regression model. If the correlation is proven high between the independent variables, then the connection between independent and dependent variables may experience issues. In a good regression model, there should not be any multicollinearity. Boedjiwonno (2007) in their book explains that the cause of multicollinearity can be seen by looking at the VIF and Tolerance value or by comparing the partial determination value $\left(\mathrm{r}^{2}\right)$ and simultaneous determination value $\left(\mathrm{R}^{2}\right)$. To test the multicollinearity in the basis of decision making, if the $r^{2}$ coefficient number is less than $\mathrm{R}^{2}$, thus no multicollinearity occurred.

Based on the above table, it is known that the $\mathrm{r}^{2}$ coefficient from all partially independent variables has a smaller number than the $\mathrm{R}^{2}$, which is $0.024<0.246$ and $0.001<0.246$. Thus, it can be concluded that in this regression model, multicollinearity does not occur.

\section{d. Autocorrelation Test}

The autocorrelation test is conducted to understand if there is a correlation between the residuals on an observation compared to another in different time-frame. The regression analysis is conducted to find out the effect of independent variables toward dependent variables so that there will not be any correlation between the present observation data and the previous one. The autocorrelation test in this research is using Durbin-Watson test.

Based on the result of the autocorrelation test, it is found that the Durbin-Watson value is 1.838. This value will be compared to Durbin-Watson table value with $\alpha=5 \%$ significance value. With the total number of samples of 30 (n) and the total of independent variables of $2(\mathrm{k}=2)$, the $\mathrm{dU}$ value is 1.5666 . It can be considered that the Durbin Watson value of 1.838 is greater than the dU value of 1.5666 and less than $4-\mathrm{dU}$, 2.4334, ( $\mathrm{dU}<\mathrm{d}<4-\mathrm{dU})$. It, then, can be concluded that there is no autocorrelation for Mudharaba financing variable.

\section{Hypothesis Testing}

The hypothesis testing in this research is conducted using multiple regression analysis method. The output of the multiple regression analysis can be found on the correlation, determination $\left(\mathrm{R}^{2}\right), \mathrm{F}$ test, and t-test analysis to understand if the independent variables are partially and simultaneously affecting the dependent variables.

Table 4. Multiple Regression Analysis Output

\begin{tabular}{lcccl}
\hline Variables & B & t & Sig. & \multicolumn{1}{c}{ Conclusion } \\
\hline Constants & $-1,967$ & & & \\
Mudharaba & 0,588 & 2,963 & 0,006 & Positive Significant \\
Musharaka & $-0,507$ & $-1,618$ & 0,009 & Negative Significant \\
F & 4,406 & & 0,022 & Significant \\
R & 0,496 & & & \\
R Square & 0,246 & & & \\
\hline
\end{tabular}

Source: Processed data 
Based on Table 4, the equation of the regression can be arranged below: $\mathrm{PROF}=(-1,967)+0,588 \mathrm{MUDH}+(-507) \mathrm{MUSY}$

The above equation shows that the value of constant -1.967 . This means, if the Mudharaba and Musharaka variables are considered constant (Mudharaba and Musharaka $=$ $0)$, the value of profitability (PROF) will be negative (-1.967). The regression coefficient variable of Mudharaba financing $(\mathrm{MUDH})$ is 0.588 , which means if the other independent variables are constant and the Mudharaba financing variable is increasing 1 unit, then the profitability will increase as much as 0.588 . The positive value of the coefficient means that there is a positive relationship between Mudharaba financing and profitability level. The higher the Mudharaba financing, the higher the profitability level.

The regression coefficient variable of Musharaka financing (MUSY) is -0.507 , which means if the other independent variables are constant in value and the Musharaka financing variable increase 1 unit, then the profitability will decrease as much as 0.507 . The negative coefficient shows that there is a negative relationship between Musharaka financing and profitability level. The higher the Musharaka financing, the less the profitability level.

\section{a. Correlation Analysis}

This analysis is used to understand the relationship tightness between independent and dependent variables. When the $\mathrm{R}$-value is closer to 1 , it shows a good relationship between the two variables. Meanwhile, when the $\mathrm{R}$-value is closer to 0 , it shows a weaker relationship between the two variables. Based on Table 4, the R-value is 0.496. This number shows that there is a fairly strong relationship between Musharaka and Mudharaba financing toward profitability level.

\section{b. Determination Analysis $\left(\mathbf{R}^{2}\right)$}

The determination coefficient $\left(\mathrm{R}^{2}\right)$ is used to understand the percentage proportion of the effect of the independent variables toward the dependent ones. If $\mathrm{R}^{2}=0$, thus the independent variables do not affect the dependent variables or the regression model does not show any explanation from the dependent variables. Meanwhile, if $\mathrm{R}^{2}=1$ means that independent variables affect dependent variables perfectly or the regression model may explain the dependent variables $100 \%$.

Based on Table 4, the value of $\mathrm{R}^{2}$ is 0.246 , which means the independent variables (Mudharaba and Musharaka financing) contribute $24.6 \%$ to the dependent variable (profitability). In the other words, the independent variables can explain the dependent variable as much as $24.6 \%$ while the other $75.4 \%$ may be able to be explained by other variables that are not included in the research model.

\section{c. F Test}

The $\mathrm{F}$ test is used to understand the simultaneous effect of independent variables toward the dependent variable. Table 4 shows the significance value of profitability as much as 0.222 which means smaller number than the significance rate of $\alpha=5 \%(0.022<0.05)$ and the value of $\mathrm{F}$ count is 4.406 which greater than the $\mathrm{F}$ table of $3.35(4.406>3.35)$. Based on the result of sig. and $\mathrm{F}$ count value within the $\mathrm{F}$ test, it can be considered that $\mathrm{H}_{0}$ is rejected, so that the Mudharaba and Musharaka financing simultaneously affect the profitability level of Commercial Islamic Bank on 2012-2016.

\section{d. T-Test}

The t-test is conducted to measure the partial effect of independent variables toward dependent variables. Table 4 shows that the value of significance probability for Mudharaba financing is 0.006 . This number shows a smaller number than the significance 
rate of $5 \%(0.006<0.005)$ and the value of $t$ count is 2.963 which is greater than the $t$ table value of 1.70329 (2.963>1.70329). Based on the sig. and $t$ count value within the $t-$ test, it can be concluded that $\mathrm{H} 0$ is rejected, so that, partially, the Mudharaba financing has a significant effect on the profitability level of Commercial Islamic Bank in 20122016.

Table 4 also shows the value of significance probability for Musharaka variable as much as 0.009 which indicates a smaller number than the significance rate of $5 \%$ $(0.009<0.05)$ and the value of $t$ count $(-1.618)$ is also smaller than the $t$ table value $(-$ 1.70329) $(-1.618<-1.70329)$. Based on the result of sig. and $t$ count value in the $t$-test, it can be concluded that $\mathrm{HO}$ is rejected. Thus, partially, Musharaka financing has a significant effect on the profitability level of the Commercial Islamic Bank during 2012-2016.

\section{Conclusion}

1. The effect of Mudharaba financing toward profitability level of Commercial Islamic Bank. The Mudharaba financing variable has a significant impact on the profitability level of the Commercial Islamic Bank on the period of 2012-2016. It is proven by the probability significance value of 0.006 which shows a smaller number than the significance rate of $5 \%$ $(0.006<0.05)$ and $t$ count value of 2.963 which is greater than the $t$ table value of 1.70329 $(2.963>1.70329)$. The regression coefficient which is 0.588 in value shows that every increase as much as 1 unit on Mudharaba financing variable will cause the increase in profitability level as much as 0.588 . The positive value of the coefficient means that there is a positive relationship between Mudharaba financing and profitability level. The higher the Mudharaba financing, the higher the profitability level.

2. The effect of Musharaka financing toward profitability level of Commercial Islamic Bank. The Musharaka financing variable has a significant impact on the profitability level of the Commercial Islamic Bank on the period of 2012-2016. It is proven by the probability significance value of 0.009 which shows a smaller number than the significance rate of $5 \%$ $(0.009<0.05)$ and $t$ count value of -1.618 which is less than the $t$ table value of 1.70329 $(2.963>1.70329)$. The regression coefficient which is -0.507 in value shows that every increase as much as 1 unit on Musharaka financing variable will cause a decrease in profitability level as much as 0.507 . The negative value of the coefficient means that there is a negative relationship between Musharaka financing and profitability level. The higher the Musharaka financing, the less the profitability level.

3. Mudharaba and Musharaka financing variables have a significant effect on the profitability level of the Commercial Islamic Bank from 2012 to 2016. It is proven by the significance value of 0.222 which shows a smaller number than the significance rate of $5 \%(0.022<0.05)$ and the $\mathrm{F}$ count value is 4.406 which is greater than the $\mathrm{F}$ table value of $3.35(4.406>3.35)$.

4. Based on the research results, it can be concluded that the proposed hypothesis 1,2 , and 3 is linear with results, although the results of the direction are different from the proposed hypothesis. Partially, Mudharaba financing has a significant and positive effect on profitability level. Meanwhile, Musharaka financing variable, partially, has a significant and negative effect on profitability level. Simultaneously, all independent variables (Mudharaba and Musharaka financing) have a significant effect on the profitability level of the Commercial Islamic Bank during 2012-2016.

\section{References}

Aditya, M.R. (2016). Pengaruh Pembiayaan Mudharaba dan Pembiayaan Musharaka terbadap Tingkat Profitabilitas Bank Umum Syariah Periode 2010-2014. Skripsi. Fakultas Ekonomi Universitas Negeri Yogyakarta. 
Afif, Z.N., \& Mawardi, I. (2014). Pengaruh Pembiayaan Murabahah terhadap Laba melalui Variabel Intervening Pembiayaan Bermasalah Bank Umum Syariah di Indonesia Periode 2009-2013. JESTT. 1(8).

Boedijoewono, N. (2007). Pengantar Statistika Ekonomi dan Bisnis. Jilid 2. Yogyakarta: UPP STIM YKPN

Botis, S. (2013). Shari'ah Concepts in Islamic Banking. Bulletin of the Transilvania University of Brasov Series V: Economic Sciences. 6(55) No. 2

Chlalifah, E., \& Sodiq, A. (2015). Pengaruh Pendapatan Mudharaba dan Musharaka Terhadap Profitabilitas (ROA) Bank Syariah Mandiri Periode 2006-2014. Equilibrium: Jurnal Ekonomi Syariah. 3(1).

Fatmawati, R. (2016). Analisis Pengarub Pembiayaan Mudharaba, Musharaka, dan Murababah terbadap Kemampu Labaan BPR Syariah Artha Surya Barakah Semarang. Skripsi. Fakultas Ekonomi Universitas Muhammadiyah Semarang.

Haeruddin, M.I.M. (2016). Mudharaba Savings Influence on Profitability at Shariah Banks (Makassar, Indonesia). Journal Actual Problems of Economics. No 176

Horne, J.C.V., \& Wachowicz, J.M. (2013). Prinsip-Prinsip Manajemen Kenangan. Edisi 13 Buku 1. Jakarta: Salemba Empat

Ismail, A.G.B., \& Tohirin, A. 2010. Islamic Law and Finance. Jurnal Humanomics. 25 (3), 178-199.

Izhar, H., \& Asutay, M. (2007). Estimating the Profitability of Islamic Banking: Evidence from Bank Muamalat Indonesia. Review of Islamic Economics. 11(2), 17-29

Kayed, R. N. (2012). The entrepreneurial role of profit-and-loss sharing modes of finance: theory and practice. International Journal of Islamic and Middle Eastern Finance and Management. 5(3), 203-228

Khan, M. (2011). Islamic Banking Practices: Islamic Law and Prohibition of Riba. Jurnal Islamic Studies. 50 (3/4), 413-422

Muhammad. (2005). Manajemen Pembiayaan Bank Syariah. Yogyakarta: Unit Penerbitan dan Percetakan, Akademi Manajemen Perusahaan (YKPN).

Permata, R.I.D., Yaningwati, F., \& Z.A, Zahroh. (2014). Analisa pengaruh pembiayaan Mudharaba dan Musharaka terhadap tingkat profitabilitas (Return On Equity). Jurnal Administrasi Bisnis. 12(1).

Riyadi, S., \& Yulianto, A. (2014). Pengaruh Pembiayaan Bagi Hasil, Pembiayaan Jual Beli, Financing To Deposit Ratio (FDR) dan Non Performing Financing (NPF) Terhadap Profitabilitas Bank Umum Syariah di Indonesia. Accounting Analysis Journal. 3(4).

Sekaran, U. (2011). Research Methods for Business Metodologi Penelitian untuk Bisnis. Edisi 4 Buku 1. Jakarta: Salemba Empat

Suntoyo, D. (2007). Analisis Regresi dan Korelasi Bivariat. Yogyakarta: Amara Books

Wibowo, A., \& Sunarto. (2015). Pengaruh Pembiayaan Mudharaba dan Musharaka Terhadap Profitabilitas Perbankan Syariah (Studi Kasus Pada Bank Pembiayaan Rakyat Syariah Daerah Istimewa Yogyakarta yang Terdaftar di Bank Indonesia Periode 2012-2014). Syariah Paper Accounting FEB UMS, 115-124.

Wulandari, P., Kassim, S., Sulung, L.A.K., \& Putri, N.I.S. (2016). Unique Aspects of The Islamic Microfinance Financing Process Experience of Baitul Maal Wa Tamwil in Indonesia. Humanomics Journal. 32(3), 230-247 
www.bi.go.id accessed on April 15, 2017

www.bankmuamalat.co.id

www.brisyariah.co.id

www.syariahmandiri.co.id

www.bnisyariah.co.id

www.paninbanksyariah.co.id

www.bcasyariah.co.id. 